\title{
Effect of Low-Dose Electron Radiation on Rat Skin Wound Healing
}

\author{
Solange Maria de ALMEIDA ${ }^{1}$ \\ Adriana Dibo da CRUZ ${ }^{1}$ \\ Rívea Inês FERREIRA ${ }^{2}$ \\ Mário Roberto VIZIOLI ${ }^{3}$ \\ Frab Norberto BÓSCOLO ${ }^{1}$
}

\begin{abstract}
${ }^{1}$ Department of Oral Diagnosis, School of Dentistry of Piracicaba, State University of Campinas, Piracicaba, SP, Brazil
${ }^{2}$ Department of Pediatric Dentistry and Orthodontics, São Paulo City University, São Paulo, SP, Brazil

${ }^{3}$ Department of Oral Pathology, School of Dentistry of Piracicaba, State University of Campinas, Piracicaba, SP, Brazil
\end{abstract}

\begin{abstract}
The aim of this study was to assess the effect of low-dose electron irradiation on morphological features of the wound healing process in rat skin. Surgical wounds were inflicted with a $2.3 \times 1.4 \mathrm{~cm}$ template on 84 male rats that were assigned to 4 groups: IG1, immediately irradiated; IG2, irradiated 3 days after inflicting the wound; CG1 and CG2, control groups. Rats in IG1 and IG2 groups had their wounds exposed to $1 \mathrm{~Gy}$ of $6 \mathrm{MeV}$ electron beam radiation, immediately after surgery and on the third postoperative day, respectively. Qualitative and histophotometric evaluations of tissue repair structures were carried out. Data were analyzed by ANOVA and Tukey's test $(\alpha=0.05)$ and regression analysis. The repair process was delayed since the first sacrifice time in both irradiated groups, but in IG1, wound healing was closer to that of CG1; whereas in IG2, the delay was more pronounced. Based on the histological findings, it is possible to conclude that a low-dose of electron radiation delayed tissue repair in rat skin. The delay was longer in the skin irradiated 3 days after the beginning of tissue repair. However, the low-energy electron irradiation did not prevent wound healing.
\end{abstract}

Key Words: radiation, ionizing, radiotherapy, wound healing, histology.

\section{INTRODUCTION}

During the last few decades, there have been substantial improvements in cancer treatment optimization $(1,2)$ and radiotherapy, which is currently an important part of several cancer treatments, can be indicated for patients in the postoperative phase. The challenge with all types of radiotherapy is to destroy the tumor cells without damaging normal tissue (3). Typically, with conventional treatment techniques, often employing parallel-opposed fields, only a small proportion of the normal tissue is within the irradiated volume and will receive a relatively high dose per fraction. With the introduction of conformal and intensity modulated radiotherapy (IMRT), a relatively larger normal tissue volume will typically be irradiated with a low-dose per fraction (4).

Normal skin has an inherent radiosensitivity and is sometimes affected by irradiation, depending on the dose, field size, fraction regimen and quality of the radiation beams $(5,6)$. Nevertheless, the relationship between irradiation parameters, complications, and tumor control is complex and still not precisely defined for most cancers and normal tissues (5-7).

Electron irradiation has become readily available for use in radiotherapy. This procedure determines great differences in depth-dose distribution, when compared to photon irradiation, thus enabling the delivery of a maximal dose to skin and subcutaneous tissue $(8,9)$. Electron irradiation promotes a high entry dose at skin and a rapid fall in energy with depth, minimizing the systemic effects of ionizing radiation (9). However, even with a low-dose, local effects of electron radiation can occur and the surrounding normal tissue can be affected. This interaction can be related to some alterations in wound healing after

Correspondence: Adriana Dibo da Cruz, Departamento de Diagnóstico Oral, Avenida Limeira, 901, Areião, 13414-903 Piracicaba, SP, Brasil. Tel.: +55-19-2106-5327. Fax: +55-19- 2106-5218. e-mail: cruz_a_d@fop.unicamp.br 
surgery for tumor extirpation (10).

The repair process presents a well-defined pattern, which begins with granulation tissue organization by the 7 th day of development $(11,12)$. It should be mentioned that the newly formed tissue will not necessarily have the same characteristics as the tissue it replaces. This means that tissue repair can be modified by some intrinsic and extrinsic factors (10). Ionizing radiation is an extrinsic factor that influences the tissue repair process $(5,8,10)$.

Previous experiments have demonstrated the inhibitory effect of x-radiation on newly formed connective tissue proliferation, which varied according to radiation delivery time in relation to the wound healing stage (5$9,13,14)$. This explains why the side effects of radiotherapy can be divided into acute and late side effects. The late side effects occur months or even years after treatment, depending mainly on disturbances in microvascularity and connective tissue. On the other hand, the acute effects occur immediately or within a few days after irradiation (6). Both the late and acute irradiation side effects can be irreversible. Currently available knowledge about the pathogenesis of radiation-induced normal tissue injury has brought information for identifying tissue repair potential to prevent the side effects of irradiation $(6,7)$.

Despite the great number of previous investigations in radiobiology $(4,5,7,8,10,13-17)$, few studies have focused on the quantitative analysis of glycosaminoglycans (GAGs) in the granulation tissue of locally irradiated skin. Scientific evidences indicate that the influence of irradiation on connective tissue leads to the degradation of ground substance and produces severe disturbances in the metabolism of GAGs (10).

Therefore, the purpose of the present study was to perform qualitative evaluations of granulation tissue components and histophotometric measurements of GAGs after low-dose electron irradiation in rat skin wounds.

\section{MATERIAL AND METHODS}

The experimental protocols described in this paper were approved by the Ethical Committee for Animal Research of the Institute of Biology, State University of Campinas (CEEA).

Eighty-four male Wistar rats (Rattus norvegicus, albinus), aged 80 days and weighing 200-250 g, were selected. The animals were anesthetized with $3 \%$ pentobarbital sodium in a single dose of $40 \mathrm{mg} / \mathrm{kg}$ of body weight, administered intraperitoneally. Digital shaving was performed on the right median dorsal region of each animal. Subsequently, the animals underwent a surgical procedure in order to make a standardized skin wound, with a $2.3 \times 1.4 \mathrm{~cm}$ template on the dorsal area without piles. After surgery, the rats were assigned to 4 groups according to the irradiation regimen: Irradiated Group 1 (IG1) - irradiated immediately after the surgical procedure; Control Group 1 (CG1) - non-irradiated animals, as control for IG1; Irradiated Group 2 (IG2) - irradiated three days after the surgical procedure; and Control Group 2 (CG2) - non-irradiated animals, as control for IG2.

Before irradiation, rats in IG1 and IG2 groups were anesthetized with $3 \%$ pentobarbital sodium in a single dose of $40 \mathrm{mg} / \mathrm{kg}$ of body weight, administered intraperitoneally. Only an approximately $1-\mathrm{cm}$-wide area around the wounds was exposed to $6 \mathrm{MeV}$ electron beam irradiation with a single dose of $1 \mathrm{~Gy}$, using a linear accelerator Mevatron $^{\circledR}$ (Siemens Medical Solutions, Malvern, PA, USA), at a target-to-source distance of $100 \mathrm{~cm}$. The electron beam had uniform penetration to a depth of $1 \mathrm{~cm}$ in the skin. The wound and the rest of the animal's body were otherwise shielded by $4 \mathrm{~mm}$ of lead. The rats in CG1 and CG2 groups received anesthesia with $3 \%$ pentobarbital sodium to induce the homologous stress situation of IG1 and IG2, but were not exposed to radiation.

Wound healing was examined at 2, 4, 7, 11, 14, 17 and 21-day time intervals after irradiation. The animals were sacrificed by anesthetic overdose with $3 \%$ pentobarbital sodium and the entire wound region was excised in depth with liberal margins of surrounding skin to include underlying connective tissues above the external fascia of the dorsal muscles. The excised skin was fixed in $10 \%$ formalin, dehydrated in graded alcohol solutions, embedded in Paraplast ${ }^{\circledR}$ plus (Oxford Labware, Memphis, TN, USA) and cut in 5- $\mu \mathrm{m}$-thick serial sections. The following histological methods were used: hematoxylin-eosin staining for morphological evaluation; Del Rio-Hortega's silver impregnation for observations under polarized light; and $0.025 \%$ toluidine-blue aqueous solution at $\mathrm{pH} 4$ histochemical reaction for histophotometric measurements of GAGs.

Histophotometric analysis was accomplished with a microscope photometer Axiolab Pol ${ }^{\circledR}$ (Carl Zeiss AG, Jena, Germany) with $\times 16$ magnification and monochromatic light at $540 \mathrm{~mm}$. Each lamina was all scrutinized with 10 measurements to obtain the resultant averages of absorbance. General means at each sacrifice time were calculated. 
The first and second histological methods provided a descriptive assessment of granulation tissue structures, while the third method yielded a quantitative appraisal of the GAGs. The amounts of GAGs in the granulation tissue at the sacrifice time were compared using ANOVA and Tukey's test $(\alpha=0.05)$. Regression analysis was used to evaluate the alterations in the amounts of GAGs at the several sacrifice times.

\section{RESULTS}

\section{Hematoxylin-Eosin Staining}

In all studied groups, lack of tissue organization was observed two days after irradiation, which is characteristic of the initial phase of the repair process. Specimens from irradiated groups exhibited this phe- nomenon more severely. Furthermore, it was possible to observe a delay in the development of the granulation tissue in specimens obtained from irradiated animals in all subsequent examination sets during the repair process. This delay in tissue development was characterized by low amount of collagen fibers and reduced number of inflammatory cells in comparison to the control specimens. Although electron irradiation determined a delay in granulation tissue development, the deleterious effect was more pronounced in the specimens from IG2, i.e. when the ionizing radiation was administered three days after wounding (Fig. 1).

\section{Silver Impregnation and Birefringence}

The granulation tissue in the specimens obtained from control animals presented an increased collagen
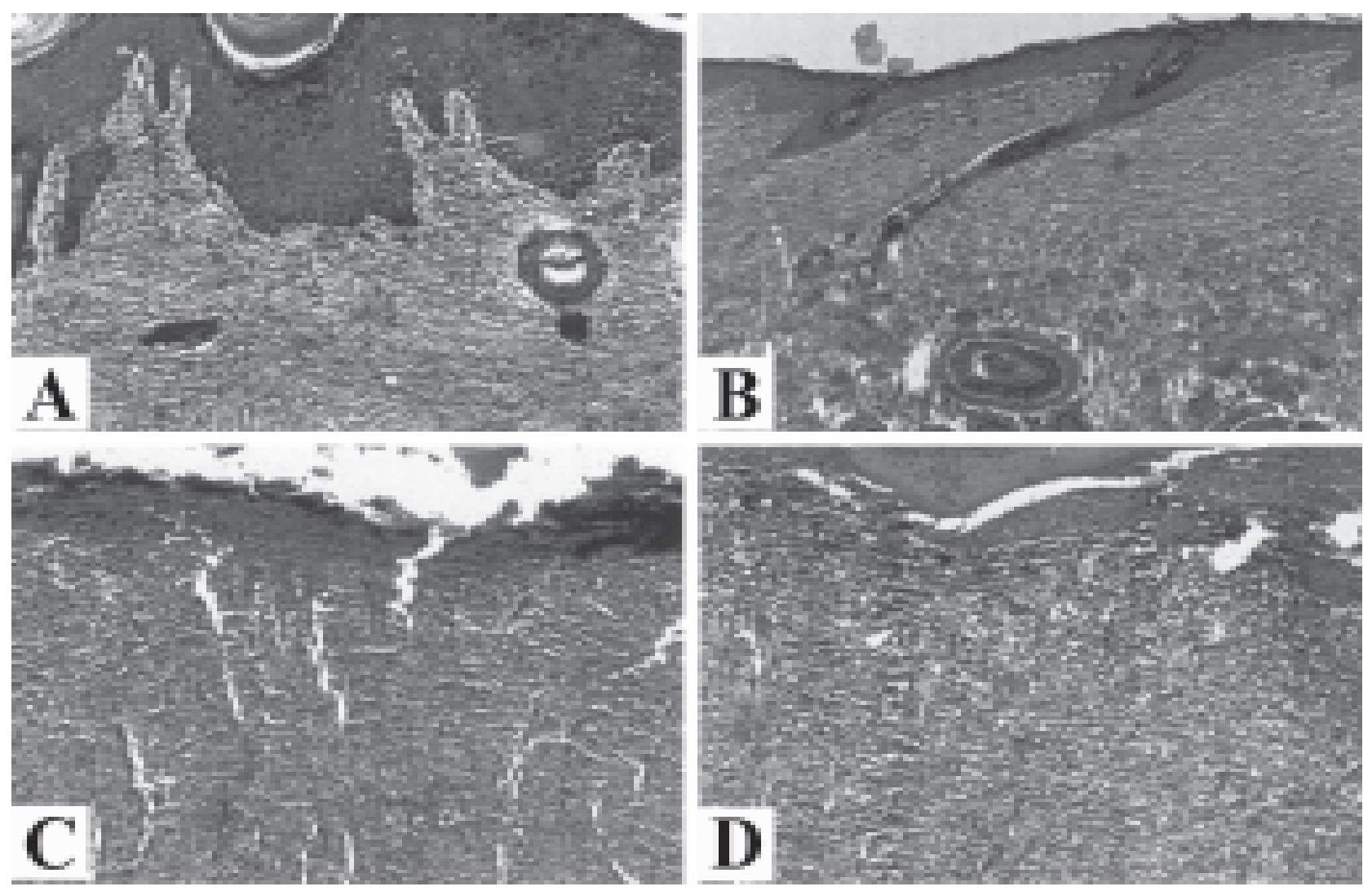

Figure 1. Photomicrographs of the granulation tissue on the 14 th day after irradiation (HE, original magnification: $\times 200$ ). A $=$ Specimen from CG1 showing a normal pattern of granulation tissue development, relatively well-fibrosed and covered by epithelium; B = Specimen from CG2 presenting a normal pattern of wound healing, in an advanced stage compared with CG1. The epithelium layer became thinner; $\mathrm{C}=$ Specimen from IG1 exhibiting a delayed pattern of tissue development in relation to CG1; D = In the specimens from IG2, collagen fibers appeared more loosely packed and there was almost complete absence of epithelium. 
formation as part of the normal repair process. Collagen bundles, at first delicate, gradually became denser and darker, thereby resulting in greater darkness when examined under usual light. These textures were also observed in the specimens from irradiated groups, though to a less intense degree (Fig. 2). In the control groups, collagen fibers appeared more packed and better aligned when compared to those from the irradiated specimens.

\section{Toluidine-Blue Histochemical Reaction}

Data relative to the histophotometric measurements of GAGs content are described in Table 1 and Figure 3. According to Table 1, there were significant differences in GAGs measurements between the irradiation times.
Interestingly, in the control groups' row, there were statistically significant differences $(p<0.05)$ at all studied sacrifice times, except for the 7th day. Figure 3 demonstrates that specimens from CG1 and CG2 were in different healing stages, corroborating that CG2 was in a more advanced phase. Statistically significant differences $(p<0.05)$ were found between control and irradiated groups at all sacrifice times, most frequently between CG2 and IG2 (Table 1). The greater GAGs content observed in the specimens from the irradiated groups indicates the delayed macromolecular organization of the granulation tissue, in comparison to the control groups. Based on the data presented in Figure 3, it is possible to note that IG1 and IG2 exhibited a similar behavior in terms of GAGs content alterations throughout the studied period due to a delay in the repair process.
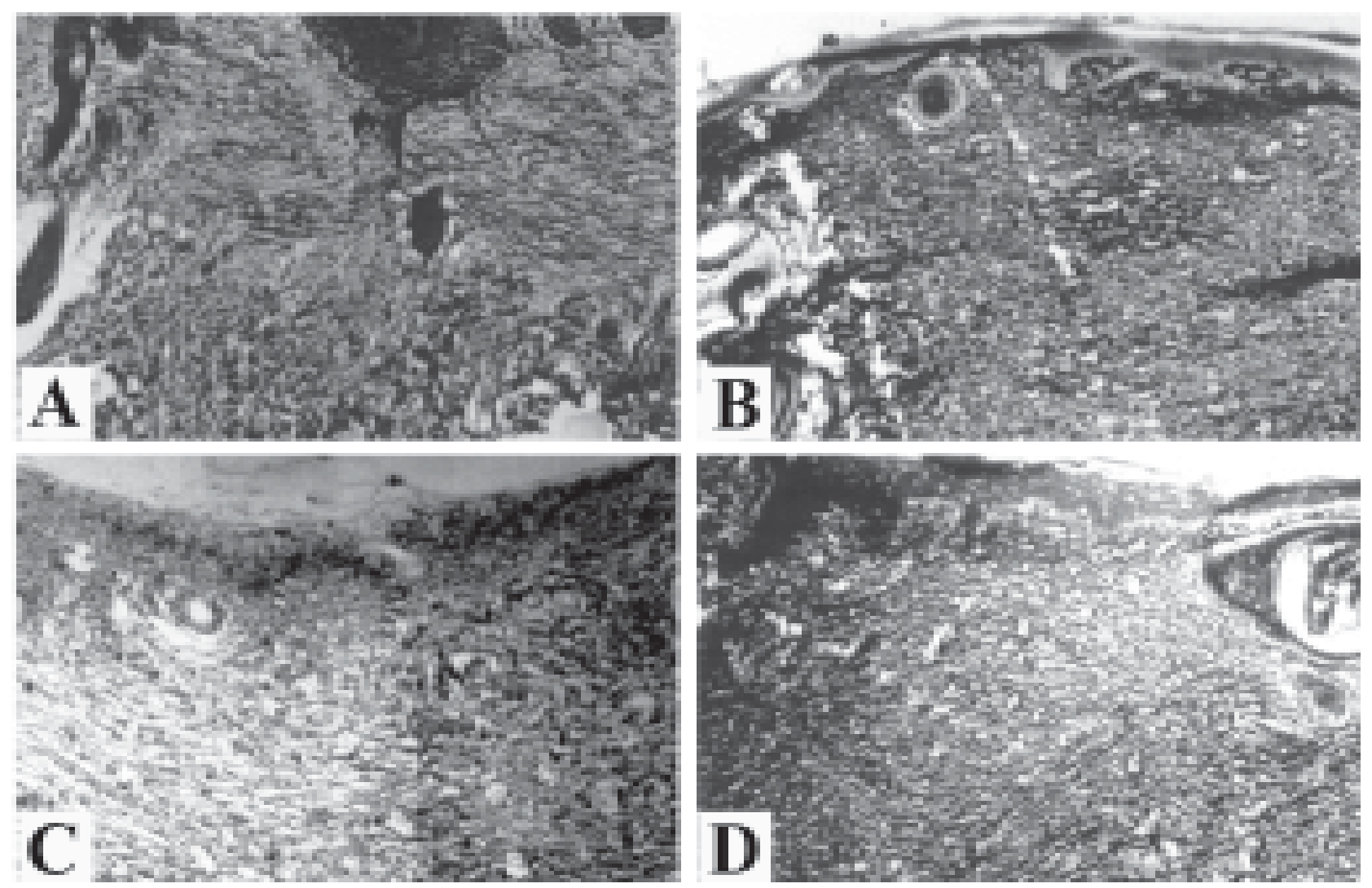

Figure 2. Photomicrographs of the granulation tissue on the 14th day after irradiation (argentic impregnation under usual light - original magnification: $\times 200$ ). A and B = Specimens from CG1 and CG2, respectively, exhibiting an intense dark birefringence, indicating the concentration of tightly-packed matured collagen; $\mathrm{C}=$ Specimen from IG1 showing a delayed pattern of collagen bundle development, as expressed by less packed collagen fibers in comparison with $\mathrm{CG1}$; D = Specimen from IG2 presenting weakly birefringent fibers, consistent with reduced collagen content. 
Table 1. Means and standard deviations (SD) of GAG histophotometric measurements according to the sacrifice time.

\begin{tabular}{|c|c|c|c|}
\hline $\begin{array}{l}\text { Day of } \\
\text { sacrifice } \\
\text { after } \\
\text { irradiation }\end{array}$ & $\begin{array}{c}\text { Day of } \\
\text { irradiation } \\
\text { after } \\
\text { surgery }\end{array}$ & $\begin{array}{l}\text { Control } \\
\text { group }\end{array}$ & $\begin{array}{l}\text { Irradiated } \\
\text { group }\end{array}$ \\
\hline \multirow[t]{2}{*}{ 2nd } & 0 & $0.08(0.01) \mathrm{bB}$ & $0.09(0.01) \mathrm{bA}$ \\
\hline & $3 \mathrm{rd}$ & $0.11(0.01) \mathrm{aB}$ & $0.12(0.01) \mathrm{aA}$ \\
\hline \multirow[t]{2}{*}{4 th } & 0 & $0.10(0.01) \mathrm{bA}$ & $0.11(0.00) \mathrm{bA}$ \\
\hline & $3 \mathrm{rd}$ & $0.20(0.00) \mathrm{aB}$ & $0.25(0.01) \mathrm{aA}$ \\
\hline \multirow[t]{2}{*}{7 th } & 0 & $0.20(0.00) \mathrm{aB}$ & $0.23(0.00) \mathrm{aA}$ \\
\hline & $3 \mathrm{rd}$ & $0.20(0.00) \mathrm{aB}$ & $0.21(0.00) \mathrm{bA}$ \\
\hline \multirow[t]{2}{*}{11 th } & 0 & $0.19(0.00) \mathrm{aA}$ & $0.20(0.00) \mathrm{aA}$ \\
\hline & $3 \mathrm{rd}$ & $0.09(0.00) \mathrm{bB}$ & $0.13(0.01) \mathrm{bA}$ \\
\hline \multirow[t]{2}{*}{14 th } & 0 & $0.09(0.00) \mathrm{aB}$ & $0.10(0.01) \mathrm{aA}$ \\
\hline & $3 \mathrm{rd}$ & $0.07(0.00) \mathrm{bB}$ & $0.10(0.00) \mathrm{aA}$ \\
\hline \multirow[t]{2}{*}{17 th } & 0 & $0.07(0.00) \mathrm{aA}$ & $0.08(0.00) \mathrm{aA}$ \\
\hline & $3 \mathrm{rd}$ & $0.06(0.00) \mathrm{bB}$ & $0.07(0.00) \mathrm{aA}$ \\
\hline \multirow[t]{2}{*}{21 th } & 0 & $0.06(0.00) \mathrm{aA}$ & $0.06(0.00) \mathrm{aA}$ \\
\hline & $3 \mathrm{rd}$ & $0.04(0.00) \mathrm{bB}$ & $0.05(0.00) \mathrm{aA}$ \\
\hline
\end{tabular}

Different vertical lowercase letters indicate statistically significant difference between groups, considering the irradiation delivered immediately and 3 days after wounding; different horizontal uppercase letters indicate statistically significant difference between control and irradiated groups.

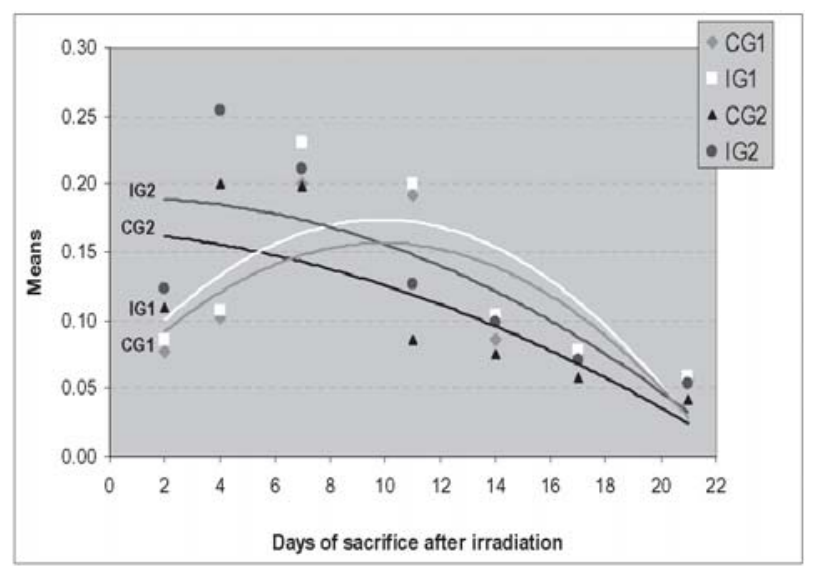

Figure 3. Regression analysis of GAG histophotometric measurements according to the sacrifice time.

\section{DISCUSSION}

In the present study, normal tissues were submitted to the action of electron radiation. The results showed that there was damage to the development of granulation tissue formed during the repair process, both in the skin irradiated immediately (IG1) and 3 days after wounding (IG2). It was also pointed out that the IG2 presented a greater impairment in the repair process than the IG1, considering data relative to their control groups.

The radiation-induced damage in granulation tissues was characterized by a delay in the repair process, particularly in IG2 at all sacrifice times. When the results of this study are compared to those obtained by Wang et al. (8) and Schäffer et al. (9), who used electron radiation, it should be noted that they also found a delay in the development of granulation tissue. Wang et al. (8) observed that the delay occurred around the 14th postoperative day. On the other hand, the findings of the present study indicate that the repair process was delayed from the first sacrifice time, in both irradiated groups; IG1 and IG2. In fact, specimens from IG1 presented histological features closer to that of the control group (CG1). Additionally, from the 14th sacrifice time, the repair process appeared similar in relation to the control group. For IG2, however, the delay was more evident and the repair process showed differences in comparison to the control group (CG2) at the different sacrifice times.

The disagreement between the results of the present study and those from the study by Wang et al. (8) probably occurred because these authors delivered irradiation 7 days before wounding, while in this investigation, the wounds were inflicted on normal tissue and the single low-dose of electron radiation was administered after wounding. The same procedure was carried out in the study conducted by Schäffer et al. (9), in which the rats were irradiated 5 days before wounding. Moreover, they did not irradiate the periphery of the incision wound, which originates the cellular elements responsible for the repair process.

In radiotherapy, both methods of radiation delivery, before and after surgery, have been used and each treatment sequence has relative advantages and disadvantages, depending on tumor volume (15). Irradiation delivered after surgery requires smaller field sizes and lower radiation doses. This procedure can be associated with less edema and fibrosis. Conversely, higher rates of wound healing complications have been reported when 
irradiation is delivered before surgery $(15,16)$.

In this experimental research, the longer delay in wound healing observed from the specimens in IG2 can be explained on the basis of Wang et al. (8) and Qu et al. $(13,14)$ findings. These authors pointed out that electron irradiation is related to a reduction in the amount of inflammatory cells and tissue exudates, a decrease in fibroblast representation and slows down epithelial migration, which in turn is associated with a delay in wound healing.

Fibroblasts are recognized as having essential importance in tissue repair. Wound contraction has been ascribed to fibroblastic activity $(8,10)$. Furthermore, the main components of the extracellular matrix, GAGs and collagen fibers, are synthesized by fibroblasts $(7,10,11,13,14)$. Wound healing can be considered complete when, after reaching maturation, the newly formed collagen reestablishes the integrity of the damaged tissue $(11,16)$. Since fibroblasts originate from cells of the surrounding undamaged connective tissue and the irradiated area comprised only an approximately 1-cm-wide zone around the wounds, it would be reasonable to assume that the observed delay in tissue repair can be attributed to direct damages in these cells.

Previous studies $(13,14)$ have suggested that impaired wound healing is caused by direct damaging effects of radiation and reduced quantities of tissuerepairing cells. It should be taken into account that in these study designs whole-body gamma irradiation was used, implying in greater systemic effects due to the deeper penetration of gamma-rays. On the other hand, the present study investigated the effect of a low LET (linear energy transfer) radiation administered locally, on the tissue surrounding the wounds.

Vizioli (11) stated that the maturation of collagen fibers only occurs when GAGs and collagen protein combine, and the organization of the granulation tissue is established when the synthesis of GAGs reaches its maximum. Any alteration in the GAGs synthesis will affect the macromolecular organization of the granulation tissue. Therefore, as mentioned by Drake and Oishi (17), the critical damage to the repair process occurs in the surrounding cells, which synthesize collagen and GAGs.

The first stage of the repair process, characterized by inflammatory response and GAGs synthesis in the granulation tissue, begins about 3 days after injury (11-13). The GAGs synthesis increases progressively as the fibroblasts proliferate and become functional. However, the GAGs synthesis decreases when the granulation tissue is already organized. These changes in GAGs content were observed by histophotometric measurements from the control specimens. Although the histophotometric analysis indicated GAGs production in the specimens from irradiated animals, the qualitative histological assessment demonstrated a delayed macromolecular organization of the granulation tissue. Hence, it can be inferred that there might have been a decrease in reactive GAGs content, presumably associated with a reduction in the population of fibroblasts in the irradiated tissue, as well as with functional alterations in these cells. The results of this study suggest that a low-dose of electron radiation can, at least, temporarily damage the normal skin. Accordingly, low-dose hyper-radiosensitivity of normal tissue can affect radiotherapy planning and parameter estimation of damage for specific tissues must be considered (4).

During the period in which wound healing was evaluated by qualitative and quantitative histological approaches, it was possible to observe that a low-dose electron irradiation, administered immediately and 3 days after surgical wounding in rat skin, caused delay in the repair process. The delay was longer in the skin irradiated 3 days after the beginning of tissue repair. However, this low-energy electron irradiation did not prevent wound healing.

\section{RESUMO}

O objetivo deste estudo foi avaliar o efeito da irradiação por baixa dose de elétrons sobre características morfológicas da reparação tecidual na pele de rato. Foram realizadas feridas cirúrgicas com um gabarito de 2,3 x 1,4 cm em 84 ratos machos, divididos em 4 grupos: IG1, irradiado imediatamente; IG2, irradiado 3 dias após a produção da ferida; CG1 e CG2, grupos controles. Os ratos dos grupos IG1 e IG2 tiveram suas feridas expostas a 1 Gy de radiação por elétrons com $6 \mathrm{MeV}$, imediatamente após a cirurgia e ao terceiro dia pós-operatório, respectivamente. Procedeu-se às avaliações qualitativas e histofotométrica das estruturas de reparação tecidual. Os dados foram submetidos a ANOVA e teste Tukey $(\alpha=0,05)$ e análise de regressão. O processo de reparação apresentou-se atrasado desde o primeiro tempo de sacrifício em ambos os grupos irradiados, mas para IG1, a reparação tecidual foi similar a CG1. Por outro lado, para IG2, o retardo foi mais pronunciado. Com base nas avaliações histológicas, é possível concluir que uma baixa dose de radiação por elétrons retardou a reparação na pele de rato. $\mathrm{O}$ atraso foi maior na pele irradiada 3 dias após o início da reparação tecidual. No entanto, esta irradiação por elétrons de baixa energia não impediu a cicatrização. 


\section{REFERENCES}

1. Brahme A. Development of radiation therapy optimization. Acta Oncol 2000;39:579-595.

2. Brahme A, Nilsson J, Belkic D. Biologically optimized radiation therapy. Acta Oncol 2001;40:725-734.

3. Anscher MS, Chen L, Rabbani Z, Kang S, Larrier N, Huang H, Samulski TV, Dewhirst MW, Brizel DM, Folz RJ, Vujaskovic Z. Recent progress in defining mechanisms and potential targets for prevention of normal tissue injury after radiation therapy. Int J Radiat Oncol Biol Phys 2005;62:255-259.

4. Honore HB, Bentzen SM. A modelling study of the potential influence of low dose hypersensitivity on radiation treatment planning. Radiother Oncol 2006;79:115-121.

5. Ando K, Koike S, Uzawa A, Takai N, Fukawa T, Furusawa Y, Aoki M, Hirayama R. Repair of skin damage during fractionated irradiation with gamma rays and low-LET carbon ions. J Radiat Res 2006;47:167-174.

6. Alber M, Belka C. A normal tissue dose response model of dynamic repair processes. Phys Med Biol 2006;51:153-172.

7. Stone HB, Coleman CN, Anscher MS, McBride WH. Effects of radiation on normal tissue: consequences and mechanisms. Lancet Oncol 2003;4:529-536.

8. Wang Q, Dickson GR, Abram WP, Carr KE. Electron irradiation slows down wound repair in rat skin: a morphological investigation. Br J Dermatol 1994;130:551-560.

9. Schäffer M, Weimer W, Wider S, Stulten C, Bongartz M, Budach W, Becker HD. Differential expression of inflammatory mediators in radiation-impaired wound healing. J Surg Res 2002;107:93-100.

10. Almeida SM, Ferreira RI, Bóscolo FN. Influence of irradiation on collagen content during wound healing in diabetic rats.
Pesqui Odontol Bras 2002;16:293-298.

11. Vizioli MR. Macromolecular organization of rat sponge-induced granulation tissue as revealed by dichroism. Acta Anat 1971;80:73-81.

12. Tibbs MK. Wound healing following radiation therapy: a review. Radiother Oncol 1997;42:99-106.

13. Qu J, Cheng T, Shi C, Lin Y, Ran X. A study on the activity of fibroblast cells in connection with tissue recovery in the wounds of skin injury after whole-body irradiation. J Radiat Res 2004;45:341-344.

14. Qu J, Cheng T, Shi C, Lin Y, Yan G, Ran X. Reduced presence of tissue-repairing cells in wounds combined with whole-body irradiation injury is associated with both suppression of proliferation and increased apoptosis. Med Sci Monit 2003;9:BR370-377.

15. Tseng JF, Ballo MT, Langstein HN, Wayne JD, Cormier JN, Hunt KK, Feig BW, Yasko AW, Lewis VO, Lin PP, Cannon CP, Zagars GK, Pollock RE, Pisters PW. The effect of preoperative radiotherapy and reconstructive surgery on wound complications after resection of extremity soft-tissue sarcomas. Ann Surg Oncol 2006;13:1209-1215.

16. Flanders KC, Major CD, Arabshahi A, Aburime EE, Okada MH, Fujii M, Blalock TD, Schultz GS, Sowers A, Anzano MA, Mitchell JB, Russo A, Roberts AB. Interference with transforming growth factor-beta/Smad3 signalling results in accelerated healing of wounds in previously irradiated skin. Am J Pathol 2003;163:2247-2257.

17. Drake DB, Oishi SN. Wound healing considerations in chemotherapy and radiation therapy. Clin Plast Surg 1995;22:3137.

Accepted May 30, 2007 